\title{
Unusual canvasses: resolving copyright infringement through the lens of community customs
}

\author{
Daniel Lintaman*
}

\begin{abstract}
The evolution of video game technology is outpacing intellectual property law. As augmented realities and online gaming environments continue to collapse the distinction between real and virtual worlds, they have rendered traditional frameworks for copyright law unworkable. Gaming environments were traditionally circumscribed by the magic circle. Video games now interact with the outside world in a way that obscures the divide between the public domain and the private. Such disruption undermines copyright's core purpose of balancing interests, and transforms issues such as implied license, fair dealing, and moral rights into enigmas. This article proposes a framework that redraws the magic circle using the consent-based customs of gaming communities. Only those who play at the vanguard have the expertise to reconcile copyright with modern video games without constraining creativity or innovation. Deferring to community norms restores compatibility between copyright and unusual canvasses while preserving the integrity of these interesting works.
\end{abstract}

Keywords: copyright, video games, tattoos, fair dealing, implied license, moral rights

\section{Introduction}

A central purpose of law is to frame issues. Just as the skilled photographer uses the camera as a tool to frame their desired image, legislative drafters utilize language as a framework for particular subjects. The purpose of copyright is to incentivize productive creativity while ensuring that the creator's product is accessible to users. This balancing act exists in order to protect expression, not ideas. The issue here is whether copyright fulfills its purpose when applied to the unusual canvas of video games. This article addresses whether video games fit within their current frame. In concluding that they do not, this article suggests an appropriate framework that effectively balances the interests of both creators and users.

Every instance of expression has a purpose. Laws are meant to reflect a society's purpose. What is included in legislation is often just as telling as what is not. The common law retains the ability to fill gaps in legislation to prevent legal systems from becoming static. In an era that might have met singularity, the common law needs an open mind. Since copyright regulates access between the public and private spheres, where an artwork is located in relation to those spheres becomes crucial in defining its relation to copyright. The Canadian Copyright $\mathrm{Act}^{1}$ delineates a list of artistic works that attract copyright protection. Preceding the list is the word 'includes' which denotes a non-exhaustive list. US copyright legislation lists its 'works of authorship' in the same way. ${ }^{2}$ This language creates expansive negative space: An adjustable framework capable of fitting a wealth of mediums, including those yet to be realized.

Classifying an artistic work for the purposes of copyright is straightforward when considering conventional, fixed art forms such as paintings, drawings, or sculpture. Anglo-American copyright law has created clear parameters to protect these works. The common law has also circumscribed a wealth of mediums that are less

\footnotetext{
Articled Student at Singleton Urquhart Reynolds Vogel LLP in Vancouver; J.D., Thompson Rivers University, Faculty of Law; B.A., University of Victoria. I would especially like to thank Jon Festinger, Q.C. for encouraging me to publish this work, helping me refine my ideas throughout the writing process, and imparting the idea of negative space. I am also grateful to my peer reviewers, and the editors of the Interactive Entertainment
}

Law Review. The inspiration for this work comes from my experience as a skateboarder and videographer. These pursuits allowed me to recognize urban architecture as an unusual canvass ripe for artistic expression. 1 Copyright Act, RSC 1985, c 42 (Copyright Act).

217 USCA $\$ 102$ (West 1976). 
predictable, including derivative works such as characters in novels, ${ }^{3}$ a steel structure in an indoor soccer complex, ${ }^{4}$ real estate listing metadata, ${ }^{5}$ and software code. ${ }^{6}$ However, the limits become increasingly vague for dynamic works produced in unusual contexts beyond the scope of traditional copyright considerations. Examples include video games with user-generated content, user-modified source code, or those that feature celebrity tattoos. These works have not been considered by Canadian courts and remain a fledgling issue in the US. Due to their transcendent interactions with the wider world, modern video game elements evoke enigmatic copyright issues in relation to fair dealing, implied license and moral rights. Developing an effective analytical framework to address these issues requires a nuanced understanding of the subculture from which the artwork is derived. Such an understanding requires a degree of competence found only within a particular game's community. When formal systems of positive law encounter negative space created by unusual canvasses, they should fill the gap by deferring to the rules developed by their respective communities through ubiquitous consensual use. Only these communities have the capability to ensure copyright remains dynamic and inclusive by contextualizing their subcultures within its broader legal framework.

The issues that stem from copyright law's relationship with video games are more pronounced under AngloAmerican copyright law. This is because the European model favours authors' rights which reduce users' ability to interact with and alter artistic works in a legally significant way. ${ }^{7}$ Therefore, the scope of this article will be limited to a comparative assessment of unusual canvasses as they interact with the legal frameworks of Anglo-American jurisdictions. American jurisprudence sheds some light on potential copyright issues in video games. In Canada, the Copyright Act defines artistic works expansively. And since 2002, ${ }^{8}$ Canadian courts have increasingly followed the American and international 'balancing of interests' approach, especially emphasizing users' rights after 2012. By now it is safe to say that unusual canvasses such as video games constitute artistic works protected by copyright. However, infringement claims still boil down to the contextual location of the canvas, and a communal understanding of its intended use. Legal disputes arise at the vanguard of the public and private spheres and involve a delicate balancing of interests. Such disputes are difficult to resolve because they involve an inherently interactive process across the public-private divide.

Traditionally, the public domain of video games has been circumscribed by a 'magic circle' that shrouded gameplay from legal intrusion. However, the distinction between author and user becomes obscured when a user's interactions with the canvas alter its very essence. In other words, copyright law struggles to regulate the enigmatic authorial user. So rather than regulate using a top-down approach, the time is ripe for gaming communities to redraw the magic circle. Pervasive insular rules formed by strong community bonds have now transcended the traditional magic circle to achieve judicial recognition. Drawing on existing principles of contract; judicial deference; and more broadly, subsidiarity, sophisticated consent-based communities should be able to set out their own rules that apply in 'real life', especially when that concept is becoming increasingly illusory.

\section{Motivations for claiming copyright infringement}

Copyright infringement occurs when a work is used without the owner's consent in a manner that 'only the owner of the copyright has the right to do'. ${ }^{10}$ Copyright can thus be licensed, transferred by consent, or sold by the owner. ${ }^{11}$ There are three theories that are central in explaining artists' motives for making infringement claims: economic, property, and free speech. With regard to video games, copyright infringement claims seem to be driven by an affront to the work that alters its essence, either by changing its intended message, or disrupting its status within a subculture. This is exemplified by 'mods' modifications to a video game's source code - which are
3 Anne of Green Gables Licensing Authority Inc v. Avonlea Traditions Inc [2000] 4 CPR (4th) 289, (Ont Sup Ct).

4 Lainco Inc v. Commission scolaire des Bois-Francs, 2017 FC 825.

5 Century 21 Canada Ltd Partnership v. Rogers Communications Inc, 2011 BCSC 1196.

6 Andrews v. McHale, 2016 FC 624

7 According to Peter Baldwin, the more culturally conservative authors' rights tradition insists 'that the creator retain the final say on a work's form which hinders collective and collaborative efforts, let alone acknowledgement of the audience's role in determining a work's meaning'. Such a tradition shuns the authorial user. See Peter Baldwin, The Copyright Wars: Three Centuries of Trans-Atlantic Battle (Princeton University Press, 2014) 15.
Théberge v. Galerie d'Art du Petit Champlain Inc, 2002 SCC 34.

9 Thomas Metzinger's research on virtual embodiment introduces a theory akin to the plot of Lana and Lilly Wachowski's film, The Matrix: once we construct a system of virtual or augmented reality that is indistinguishable from real life, the argument that we are already living in a constructed reality will become irrefutable. See Joshua Rothman, 'Are We Already Living in Virtual Reality?', The New Yorker (26 March 2018), available at: https://www. newyorker.com/magazine/2018/04/02/are-we-already-living-in-virtualreality.

10 Copyright Act, s 27(1).

11 Ibid s 13(4). 
viewed as enhancements by some developers, and strictly prohibited by others. ${ }^{12}$ In any event, they are prolific.

Subcultures are often defined by narrow sets of community rules to which their participants consent and adhere. Heavy publicity and commercialization tend to remove a canvas from the underground (where the author may perceive it as rightfully belonging), which constitutes infringement for some artists. ${ }^{13}$ According to prominent commentators Christopher Buccafusco and David Fagundes, money does not play 'much of a role at all in motivating artistic production, suggesting instead that the desire for subcultural status or the intrinsic enjoyment of the creative process are stronger drivers of creative production'. ${ }^{14}$ Victor Whitmill, the artist behind Mike Tyson's infamous face tattoo, became offended when his work was replicated as a comedic device on actor Ed Helms' face in the Warner Brothers film The Hangover Part II. ${ }^{15}$ Scott Adams, creator of Dilbert, admitted that although an unsanctioned use of his comic strip likely 'helped promote his brand and enhance his viewership, he still regarded it as wrong and as a profoundly personal violation'. ${ }^{16}$ Similar motivations drove devout Christian sculptor Frederick Hart to sue Warner Brothers 'for using a likeness of his religious sculpture in the orgy scene of the film The Devil's Advocate. ${ }^{17}$

The copyright infringement cases that have dealt with unusual canvasses thus far have demonstrated different theories of copyright depending on the claimant. In the cases with artist as plaintiff, the claims have seemed to center around integrity or an undesirable association with the work. When the plaintiff is a license holder, the cases seem to be economically driven, with the claimant looking to get their piece of a lucrative venture. Perhaps unsurprisingly, these situations have arisen in highly commercialized contexts. At the core of copyright infringement claims is a balancing of interests between creator

12 For example, in the End User License Agreement that applies to Grand Theft Auto $V$, Rockstar Games prohibits the reverse engineering, or modifying or any proprietary software. See Rockstar Games End User License Agreement: License Condition (j), available at: https://www.rockstargames.com/eula.

13 Indeed, in the context of the unusual canvass that is street art, some commentators argue that 'divorcing street work from its original context in order to sell or archive it removes some of its anarchic magic, even as some of its artists have expanded their practices radically beyond alleyways and overpasses'. See Naomi Rea, 'Street Art is a Global Commercial Juggernaut With a Diverse Audience. Why Don't Museums Know What to Do With It?', Artnet News (7 August 2019), available at: https://news. artnet.com/art-world/street-art-museums-1617037.

14 Christopher Buccafusco and David Fagundes, 'The Moral Psychology of Copyright Infringement' (2016) 100(6) Minn L Rev 2433 at 2434.

15 In the film, actor Ed Helms' character gets the tattoo on his face after a night of drunken debauchery. Neither Warner Brothers nor Tyson requested Whitmill's permission to use the tattoo, despite the fact that Tyson also appeared in the film. Whitmill sued Warner Brothers, seeking a preliminary injunction against the release of the film. After balancing Whitmill's interest against the public interest in viewing the sequel to The Hangover, the court denied the injunction. Warner Brothers relied and user. In order to resolve claims effectively, proper understanding of the scope of those interests is crucial. This is the issue that strikes at the core of the relationship between copyright law and unusual canvasses.

\section{Video games as artistic works: the scope of copyright and the magic circle}

In Canada, copyright crystallizes at the moment an original work is expressed, ${ }^{18}$ and subsists for the duration of the author's lifetime plus 50 years. ${ }^{19}$ The US copyright regime provides the same term, but has established a federal registry to validate copyright protection. A copyright holder's claim is presumed valid if they have deposited an application with the US Copyright Office. ${ }^{20}$ The presumption can then be rebutted if the opposing party can adduce evidence that they have a stronger claim.

The operative provision of the Canadian Copyright Act states that 'copyright ... means the sole right to reproduce the work ... in any material form whatever. ${ }^{21}$ When the Statute of Anne ${ }^{22}$ was drafted in the early 18th century, the purpose of copyright was to monopolize the printed word to standardize communication. This was essentially an economic or proprietary purpose, which, absent myriad forms of technology, made copyrightable material much easier to delineate. In the meantime, technology has evolved immensely. The printing press is now a relic, overshadowed by the in-game chat hubs of online environments which facilitate users' ability to coordinate massive battles or construct extensive environments. As technology advances, the motives for protecting or constraining creativity advance with it. ${ }^{23}$ Copyright infringement and its underlying motivations are fluid concepts, and unusual canvasses are remarkably

on the fair use defence, the merits of which were never heard since the case settled before trial. This was unfortunate, since unlike Solid Oak Sketches (discussed in detail below) the tattoo featured prominently in marketing and advertisements for the film. See Whitmill v. Warner Bros Entertainment Inc, WL 2038147 (ED Mo 2011).

16 Buccafusco and Fagundes (fn 14) at 2435.

17 Ibid at 2436

18 Théberge (fn 8) at para 8.

19 Copyright Act, s 6. The clock starts ticking at the end of the calendar year of the author's death.

2017 USCA $\$ 408$. Notes of decisions at 10 .

21 Copyright Act, s 3(1).

22 The Copyright Act 1710, 8 Ann, c 21.

23 Perhaps the ultimate manifestation of technology transcending the traditional canvas was demonstrated in 2018 by Banksy's prank at Sotheby's auction. He installed a shredder into a traditional-looking frame to create a canvas that would shred one of his most famous works upon the crack of the auctioneer's gavel. This was the ultimate physical expression of his famous statement that 'copyright is for losers'. Much of Banksy's mass appeal arguably derives from his ability to bridge the gap between 
malleable. This creates a murky relationship. If AngloAmerican copyright frameworks seek to frame this issue with their integrity intact, they must accommodate unusual forms of expression.

The Copyright Act defines 'artistic work' as inclusive of 'paintings, drawings, maps, charts, plans, photographs, engravings, sculptures, works of artistic craftsmanship, architectural works, and compilations of artistic works'. ${ }^{24}$ Canada's leading authority on intellectual property, David Vaver asserts that we cannot 'discriminate among different schools of art', ${ }^{25}$ thereby acknowledging that canvasses come in all shapes and sizes, and appear in all types of places. Rather than constraining creativity, North American judicial interpretation of copyright law favours expression by using inclusiveness as the benchmark when defining artistic works.

Defining an artistic work for the purpose of copyright protection becomes problematic when that work is expressed on an unusual canvas. Video games are created by developers, whose copyright has been protected in the US at least since the early $1990 \mathrm{~s},{ }^{26}$ but when games are supplemented and adapted by user modifications, or 'mods', issues become ambiguous. ${ }^{27}$ Mods originated as an expressions of a subculture, but have emerged to increasingly interact with the public sphere. Nowadays, video games have evolved such that shared online environments have become the rule rather than the exception. With the rapid evolution of technology, the distinction between the real world and virtual worlds is collapsing. In this environment, the traditional conception of the magic circle becomes untenable. According to Mia Consalvo, Canada Research Chair in Game Studies \& Design, in terms of digital games, 'the inviolability of the game space is a fiction, as is the magic circle'. ${ }^{28}$ This dilemma sets the stage for what initially appears to be irreconcilable differences between this subculture and copyright: video game users filling a developer's shoes by altering their original creation beyond recognition. Thus, the magic circle must be redrawn with a framework that consults the robustly self-regulated communities closest to the vanguard, with consent as the cornerstone.

Law is outpaced by the evolution of the internet. This reality makes for issues that are difficult to frame. For instance, in online worlds where intellectual property mingles freely, the scope of copyright becomes nearly impossible to delineate. In such an environment, the vertical legal relationship between user and developer is governed by the consent that underpins freedom of contract, whereas the horizontal relationship between users remains slightly more ambiguous. At the very least, the horizontal relationship is governed by the rules of a particular community, which delineate the scope of the magic circle. The magic circle's underlying rationale is that virtual worlds are analogous to a playground, and as such, should be impervious to outside influences such as real-world law, economics, and currency. The concept finds its origins in game theory ${ }^{29}$ and was introduced to the video game context by Edward Castronova. ${ }^{30}$ Since its inception, the magic circle has been remarkably influential on judicial thinking about video games specifically, and the shared spaces and rituals of unusual artforms generally. In creating the magic circle, Johan Huizinga began with the proposition that there is no difference between play and ritual. Thus, the 'consecrated spot' is indistinguishable from the playground. ${ }^{31}$ Huizinga characterized such spaces as 'forbidden spots, isolated, hedged round, hallowed, within which special rules obtain. All are temporary worlds within the ordinary world, dedicated to the performance of an act apart'. ${ }^{32}$ Much has changed since Huizinga's Homo Ludens. Those words no longer resonate with the virtual worlds of today. With singularity on the horizon, the act is no longer performed apart from the ordinary world. ${ }^{33}$ subculture and public phenomenon. See Chris Johnston, 'Banksy auction stunt leaves art world in shreds, The Guardian, Art \& Design (6 October 2018), available at: https://www.theguardian.com/artanddesign/2018/oct/ 06/banksy-sothebys-auction-prank-leaves-art-world-in-shreds-girl-withballoon.

24 Copyright Act, s 2.

25 David Vaver, Intellectual Property Law (Irwin Law, 2011) 81.

26 Atari Games Corporation v. Oman, 979 F Supp (2d) 242 (DC Cir 1992).

27 An analogous issue arises in the context of another unusual canvass: tattoo art; especially when another artist adds to a previous artist's piece. But since this canvas manifests under the human dermis layer, tension arises between copyright infringement and bodily autonomy. Enduring standards among tattoo artists within their industry provide a generous array of users' rights that may influence judicial thinking. A recent development in the tattoo copyright jurisprudence demonstrates that these rights are able to endure litigation involving the bearer of an original tattoo inking a lucrative video game deal with a third party. See the discussion on Solid Oak Sketches v. $2 \mathrm{~K}$ Games below.
28 Mia Consalvo, 'There is No Magic Circle' (2009) 4(4) Games and Culture 408 at 411.

29 Johan Huizinga, Homo Ludens: A Study of the Play Element in Culture (Boston, Beacon Press, 1955). While the playground metaphor has gained the most traction in subsequent literature, Huizinga originally presented a much broader application. He referred to the 'arena, the card-table, the magic circle, the temple, the stage, the screen, the tennis court, the court of justice, etc.' as playgrounds in form and function. However, as Consalvo indicates, since they are elements of the physical realm, these spaces are easily envisioned as geographic space. Huizinga's conception of the magic circle needs an update in order to properly frame digital worlds. See Consalvo (fn 28) at 410.

30 Edward Castronova, 'The Right to Play' (2004) 49(1) NY L Sch L Rev 185.

31 Huizinga (fn 29) at 10.

32 Ibid.

33 In a statement that encapsulates the structuralist nature of the magic circle, Consalvo writes: 'Apart was an absolute, even if only for minutes at a time'. See Consalvo (fn 28) at 410. 
Virtual acts now ripple into the ordinary world frequently. And the ripples are beginning to look more like waves.

\section{The divide between real and virtual worlds is shrinking}

As video games continue to interact more extensively with the broader public sphere, identifying the distinction between user and creator becomes increasingly difficult. How does copyright law serve its purpose of balancing interests if the scope of those interests is indeterminable? This difficulty is apparent in mods and user-generated content, but perhaps the most striking example of the collision between virtual worlds and the real world is augmented reality. In order to remain dynamic and functional in the digital era, intellectual property law needs the adaptability to keep pace with evolving technology. This requires acknowledging that singularity in video games will manifest as a virtual world indistinguishable from reality, and that this event is approaching rapidly. In this substantial game of catch-up, law finds its greatest challenge in the development of augmented reality video games - these types of games are becoming defined less by virtual worlds, and more by real life.

A rudimentary starting point was in 2000 with the introduction of the Real-World Weather feature in Microsoft's Flight Simulator. The feature allowed players to simulate real-world weather by downloading data drawn from various weather services, which was then displayed in the simulation. ${ }^{34}$ As this technology evolved, Real-World Weather became Dynamic Weather, which then became Seasonal Weather. There is no copyright in weather data, so this was a smooth and logical development. The upcoming release of the newest generation of the game, Flight Simulator 2020 will truly put intellectual property's boundaries to the test. Judging by the trailer, the game graphics (powered by Bing satellite data and Azure AI - Microsoft's proprietary cloud computing service) will be difficult to

34 Microsoft, 'Known issues with the Real-World Weather feature in Flight Simulator', Microsoft Support (28 September 2011), available at: https:// support.microsoft.com/en-ca/help/841214/known-issues-with-the-realworld-weather-feature-in-flight-simulator.

35 Phil Iwaniuk, 'Microsoft Flight Simulator: everything we know about the boundless aviation sim', PC Gamer (23 February 2020), available at: https://www.pcgamer.com/microsoft-flight-simulator-release-date-trailer/.

36 Ibid.

37 David Spratley, 'How real is too real? Depicting real-world brands and people in video games' (26 November 2010) 30(28) The Lawyers Weekly: Focus on Intellectual Property, available at: https://www.lexisnexis.ca/en$\mathrm{ca} /$ products/the-lawyers-daily.page.

38 See Pokémon Go Death Tracker, available at: pokemongodeathtracker.com. One study determined that since its release in 2016, Pokémon Go-associated distinguish from real life. ${ }^{35}$ Indeed, the 'whole planet is mapped and modeled, ready to be flown across from tens of thousands of airports. ${ }^{36}$ Is it possible to parse the bounds of intellectual property in a model of the entire world?

Microsoft's Flight Simulator was originally created to be as realistic as possible so that aspiring pilots could experience flight from the safety of their computer chair. This appealed to the user's sense of escapism, and the game's popularity spoke to the prevalence of this desire. As gameplay approaches augmented reality, escapism becomes enhanced by increased realism. David Spratley explains: 'For golf enthusiasts, it's more interesting to play on a virtual Pebble Beach than on a made-up course; for car enthusiasts, it's more interesting to drive a virtual Impreza WRX than some made-up car. ${ }^{37}$ Thus, it was only a matter of time before developers capitalized on augmented reality's appeal by bringing it to a smart phone app.

For escapist gamers, it might be a bit unnerving to visit the website that tracks the deaths and injuries of users as a result of playing Pokémon Go absentmindedly. ${ }^{38}$ Released in 2016 by developer Niantic, Pokémon Go quickly became 'the most popular mobile game in history. Beyond its success as an app, the game marks a milestone in technology history in that it is the first successful mainstream example of augmented reality a technology that combines "real and virtual objects in a real environment"'. ${ }^{39}$ Writing for the World Intellectual Property Organization Magazine, Andres Guadamuz claims that Pokémon Go is the proof of concept of a technology that will have far-reaching implications which we have not yet even started to think about'. ${ }^{40}$ The object of the game is to capture Pokémon creatures by throwing poke-balls at them. This format builds on the long history of video games based on the Pokémon franchise, with one key difference: Pokémon Go uses augmented reality to allow players to interact with the world around them. When the Pokémon appear, they overlay actual satellite imagery 'mined from geo-tagged photos from Google'. ${ }^{41}$ Using the game's sophisticated

traffic accidents 'caused two deaths, 31 injuries, and nearly $\$ 500,000$ in vehicle damage' in one Indiana county alone. See Z. Bernard, 'Maybe you shouldn't catch 'em all - A new study links "Pokémon Go" to traffic deaths, injuries, and vehicle damage', Business Insider (27 November 2017), available at: https://www.businessinsider.com/pokemon-go-linked-to-trafficdeaths-accidents-and-hundreds-of-thousands-of-dollars-in-vehiculardamage-2017-11.

39 Andres Guadamuz, 'Pokémon Go: augmented reality tests IP', WIPO Magazine (February 2017), available at: https://www.wipo.int/wipo_magazine/en/ 2017/01/article_0005.html.

40 Ibid.

41 Ariel Bogle, 'How the gurus behind Google Earth created "Pokémon Go"', Mashable Tech News (10 July 2016), available at: https://mashable.com/ 2016/07/10/john-hanke-pokemon-go/\#xz2xJ6Lmtkq0. 
mapping system, users interact with real-world surroundings by tagging public buildings and landmarks. ${ }^{42}$ Such locations are known as Pokéstops, which 'contain in-game goods, such as pokémon eggs and potions, for use in battling opposing teams. The game also features "gyms", where users can combat other pokémon for control over a location, usually a church, park or business. ${ }^{43}$

A brief history of the game's developer illuminates how this project became a reality. John Hanke, Niantic's founder and CEO also founded Keyhole, which was acquired by Google in creating Google Earth. ${ }^{44}$ Prior to starting Niantic, Hanke had helped develop Google Maps. ${ }^{45}$ Pokémon Go was the result of an inevitable progression from Niantic's earlier augmented reality multiplayer game, Ingress. To create Ingress, 'Niantic formed a beginning pool of portal locations for the game based on ... "Things that were public artwork, that were historical sites, that were buildings with some unique architectural history or characteristic, or ... unique local businesses." 46 These locations were provided by users around the world who submitted images of their favourite places, which would become the gyms and Pokéstops that appear in the game. Essentially, Niantic created an unusual canvas by aggregating other user-generated canvasses from around the world. This raises several issues. Would contributing users have copyright claims over their photographs? Although Niantic successfully resisted a patent challenge to the geo-tagging aspect of Pokémon $\mathrm{Go}^{47}$ it remains to be seen whether copyright's less rigid rules will frame the game's inherent issues. Using Google's geodata in its user interface is what causes Pokémon to appear in actual locations. ${ }^{48}$ Presumably this is permissible under license, but perhaps business owners could invoke intellectual property protection to preclude the use of their locations as Pokéstops or gyms. Or perhaps the creators of public sculptures or street art would have a claim over the dissemination of their work in a mass distributed internet app. After all, recall that real estate listing metadata is copyrightable, ${ }^{49}$ so why would the same protection not apply to the metadata

2 Guadamuz (fn 39)

43 Ibid.

44 Bogle (fn 41).

45 Ibid.

46 Ibid.

47 Location Based Services LLC v. Niantic Inc, 295 F Supp (3d) 1031 (ND Calif 2017).

48 Some companies have capitalized on this geodata. As Dr. Guadamuz indicates in his article for the World Intellectual Property Organization Magazine, 'Niantic recently entered into an agreement with Starbucks for thousands of its coffee shops in the US to be tagged as Pokémon Go stops. Other companies are following suit, with mobile telephone companies Sprint and Radio Shack also becoming points of interest in the game'. See Guadamuz (fn 39). underlying Pokémon Go imagery? These unanswered questions are precisely what make user-generated content such a confounding intellectual property issue.

\section{User-generated content}

Video game developers are now a major part of the commercial landscape, and these corporations are increasingly welcoming users' influence on their products. Eve Online's developer CCP Games claims that the 'power belongs to the players'. In the next sentence, they defined their role not as game developer, but rather, that they 'create tools for players to create content'. ${ }^{50}$ Shortly after announcing its 2020 release date, 'Microsoft confirmed that Flight Simulator will support community content' which commentators have speculated will be fashioned after 'Minecraft Marketplace, whereby both free and paid community content is curated and presented in moderated fashion'. ${ }^{51}$ Linden Lab's Second Life also provides users with a massive online environment that permits user-generated content. In other words, users can construct and change the game's landscape. These alterations are then shared, becoming visible to other users. Second Life is inhabited by avatars that are virtual representations of the users themselves. As described by one user, people are 'forming friendships with others, building and acquiring virtual property, forming contracts, substantial business relationships and forming social organizations'. ${ }^{52}$ Second Life features 'Community Standards' in its Terms of Service which set out broad principles modeled after a code of conduct. Interestingly, the principles can be altered at the request of the game's community. ${ }^{53}$ Linden Lab also exculpates itself from any editorial responsibility over the content provided in Second Life. ${ }^{54}$ While Linden Lab has taken the express approach to modding by creating an entire world around it, when developers such as CCP or Microsoft give broad creative latitude to their users, does that not constitute an implied license to mod? A discussion on expanding the implied license doctrine as a means
49 Century 21 (fn 5).

50 The Museum of Modern Art, Gallery label from Applied Design (2 March 2013-31 January 2014), Applied Design Works, available at: https://www. moma.org/collection/works/162462.

51 Iwaniuk (fn 35).

52 Banner Witcoff, 'Real Property Dispute in a Virtual World', Lexology Patent Arcade (blog) (27 February 2020), available at: https://www.lexology.com/ library/detail.aspx?g=35b97dc9-9109-4955-a6c8-4fcca8223e58.

53 Joshua A.T. Fairfield, 'The Magic Circle' (2009) 11(4) Vand J Ent L \& Prac 823 at 834.

54 Linden Labs, 'Community Standards', available at: https://www.lindenlab. com/legal/intellectual-property-infringement-notification-policy. 
of reconciling copyright law with rapidly evolving technology proceeds below.

An important distinction lies between the legal relationship of developer and user, and the relationships between users. Joshua Fairfield claims that the issue of "whether or not an action in a virtual world gives rise to a viable cause of action depends on the scope of consent granted between each set of parties. Rights will change depending on the relationship between the parties'. ${ }^{55}$ This is a familiar issue in Second Life. By 2007, a company called Eros LLC had produced a Second Life sex aid called the SexGen Bed which enabled users to engage their avatars in sexual activities. ${ }^{56}$ As it turned out, the product was extremely popular among users, which led to piracy. Eros sued several users who had pirated the SexGen Bed for copyright infringement and was granted an injunction in at least one case. ${ }^{57}$ Commentator Andrew Murray claims that the Eros cases constitute 'confirmation, if it were needed, that traditional intellectual property rights apply in virtual environments and infringements which occur there may be pursued in real-world courts' ${ }^{58}$

Once in-game commodities attain significant realworld value, the concept of a magic circle becomes illusory. Although not in a strictly legal sense, Canadian artist Bryn Oh transcended the boundary between real and virtual world upon receiving grants from the Ontario Arts Council for her work in Second Life. ${ }^{59}$ Perhaps the prime example of virtual property transcending the magic circle is Bragg v. Linden Research Inc. ${ }^{60}$ Pennsylvania attorney Marc Bragg was an established land developer in Second Life. The case arose from a bug in Linden Lab's system which allowed Mr. Bragg to attain parcels of in-game land that was still unavailable to the public for a fraction of fair-market-value (\$300). Although Linden Lab does allow 'users to retain full intellectual property rights in their creations ingame', ${ }^{61}$ it seems that property acquired through their in-game market does not constitute such a creation. Linden Lab alleged that Mr. Bragg had exploited a bug in their system and responded by closing his account for violating their Terms of Service, thus dissolving his virtual assets. Mr. Bragg sued for breach of contract and unfair trade practices, claiming losses between $\$ 4,000$ and $\$ 6,000$.

At first instance, a Pennsylvania court struck an arbitration clause that Linden Lab attempted to rely upon, finding a lack of mutuality. The case eventually settled and Mr. Bragg's account (and assets) were restored. Settlement was likely motivated at least in part by the fact that 'the Court denied Linden's motion to compel arbitration ... its reasoning [based] on the fact that, at the time, other than Second Life, there were no other available alternatives for people to retain property rights in a virtual world'. ${ }^{62}$ In his comment on the case, Banner Witcoff postulates whether a contemporary court would have compelled arbitration, given the ubiquity and expansiveness of modern virtual worlds that have emerged since Second Life, and recent cases from the US Supreme Court which have been more favourable to arbitration clauses. ${ }^{63}$

Until Bragg v. Linden Research Inc, no one could have foreseen liability arising from fraudulent conveyancing in an online world. Now, the problem of latent liability has become exemplified by online video game realms. This is because 'when copyright owners place their works online with the intent that others make use of those works, copyright law does not have a well-developed mechanism for facilitating such use'. ${ }^{64}$ Now that virtual environments are ubiquitous, the potential for unforeseen or latent liability will continue to grow absent some checks and balances. Expanding the doctrine of implied license is one option. And it seems like a desirable approach, especially in situations where the content of a game is created not by the user, but a third-party artist.

\section{Case study: Solid Oak Sketches v. $2 K$ Games}

\subsection{Implied license}

Recall that copyright owners can assign or license their interest in whole or in part. ${ }^{65}$ Copyright owners can also license non-proprietary interests such as uses that would otherwise constitute infringement with no
55 Fairfield (fn 53) at 834.

56 Andrew Murray, Information Technology Law: The Law and Society (Oxford University Press, 2019) 107.

57 Eros LLC v. Robert Leatherwood and John Does, 1-10, 2008 WL 859523 (MD Florida, 2007).

58 Murray (fn 56) at 107.

59 Cliff Lee, 'Who still hangs out on Second Life? More than half a million people', The Globe and Mail (17 May 2017), available at: https://www.the globeandmail.com/life/relationships/who-still-hangs-out-on-second-lifemore-than-half-a-million-people/article35019213/.

60 Bragg v. Linden Research Inc, 487 F Supp (2d) 593 (ED Penn 2007).
61 Witcoff (fn 52).

62 Ibid.

63 Epic Systems Corp v. Lewis, 138 S Ct 1612 (2018); Henry Schein, Inc v. Archer \& White Sales, Inc, 139 S Ct 524 (2019).

64 Indeed, as John Sieman points out, 'the only realistic way the Internet can work is the way it does: almost all copying is done without explicit permission'. See John S. Sieman, 'Using the Implied License to Inject Common Sense into Digital Copyright' (2007) 85(3) N Carolina L Rev 885 at 886.

65 Copyright Act, s 13(4); Effects Associates, Inc v. Cohen, 908 F Supp (2d) 555 (9th Cir 1990). 
formalities, meaning that such a license can also be implied from conduct and context. ${ }^{66}$ John Sieman describes copyright law's current framework for online environments in terms of opt-in and opt-out systems. Sieman posits that the greatest conflict between these two forces derives from the fact that 'copyright law is an opt-in system and the Internet operates on an optout basis' ${ }^{67}$ This inherent incompatibility may be contrary to the intentions of both developer and user. Indeed, '[c]ommon sense suggests that many copyright owners who put their work online are not ignorant of the nature of the Internet, and certain uses of their work should be expected'. ${ }^{68}$ As will be discussed more fulsomely below, many artistic subcultures have selfregulating systems based upon community social norms that adopt a common sense approach. When thorny copyright issues arise from using an artistic work in a way that blurs the line between protected works and public domain, and 'everything else suggests the use is compatible with the wishes of the copyright owner, including industry customs and widespread public reliance, the implied license doctrine can play the role of simple common sense'. ${ }^{69}$

Implied license was applied in a recent collision between two unusual canvasses: tattoos and video games. Tattoo copyright has not yet been considered by Canadian courts. The few cases that have arisen thus far have been in the US, most of which have settled out of court. ${ }^{70}$ However, perhaps the most famous of the US tattoo copyright cases arose from the popular NBA $2 \mathrm{~K}$ video game franchise, and was recently heard on its merits. The 2014-16 iterations of the game ('the games') featured tattoos borne by professional basketball players Lebron James, Kenyon Martin, and Eric Bledsoe. The ensuing lawsuit, Solid Oak Sketches v. $2 K$ Games, involved a copyright infringement claim brought by the exclusive license holder of the tattoo images. ${ }^{71}$ The defendant, $2 \mathrm{~K}$ Games, is a subsidiary of Take-Two Interactive Software, creator of the NBA $2 \mathrm{~K}$ franchise and one of the largest video game developers in the world.

Solid Oak Sketches turned largely on the implied license doctrine, which has been described in American jurisprudence as 'a legal obligation the law imposes between certain parties where there is no actual agreement between them'. ${ }^{72}$ While this construction of implied license has led to a somewhat unintelligible approach, the doctrine is not so broad. Simply put, implied license is available when a court can impute a copyright owner's intent to grant a license. ${ }^{73}$ As for the question of when such intent can be imputed, the analysis mirrors the tort framework for material contribution to risk in contributory negligence. Thus, as Christopher Newman summarizes, 'a copyright owner who knowingly makes material contributions to the use of her work should be regarded as having the intent to license it even without making a statement to that effect'. ${ }^{74}$ David Vaver claims that courts frequently use implied license as a technique 'when they think that a copyright owner is trying to exercise her rights too extensively. ${ }^{75}$ A rationale that seemed to underpin the court's finding of an implied license in Solid Oak Sketches.

Despite adopting a narrow construction of implied license, ${ }^{76}$ the court stated that 'the undisputed factual record clearly supports the reasonable inference that
66 Ritchie v. Sawmill Creek Golf \& Country Club, [2004] OJ No 3530; British Actors Film Co Ltd v. Glover, [1918] 1 KB 299.

67 Sieman (fn 64) at 891. Copyright law is an opt-in system because the starting point is the granting of a wide range of exclusive rights to the copyright holder. It is then the copyright owner's choice to allow others to exercise those rights without infringement. The internet is an opt-out system because any device connected to the network can communicate with any other device on the network usually without permission. Sieman uses the example of Google indexing the entire web as an example of how untenable a copyright system would be that operates without some degree of implied license. Since Google indexes the entire web at least once a month, 'it may be committing copyright infringement over eight billion times a month. Because a single instance of copyright infringement can result in up to $\$ 150,000$ in statutory damages without proof of any actual damages, the potential damages in any particular month for Google's infringements could easily exceed $\$ 1,200$ trillion'. Ibid at 892 .

68 Ibid at 893.

69 Ibid at 930 .

70 Another example of tattoo copyright in video games arose in 2012 when tattoo artist Stephen Allen claimed copyright infringement against video game mogul Electronic Arts and National Football League (NFL) player Ricky Williams. Allen claimed copyright over tattoos on Williams' arms, and alleged that the defendants had copied, distributed, reproduced, and adapted or publicly displayed the tattoos on the covers of three video game titles. See Allen v. Electronic Arts, Inc., No 5:12-CV-3172 (WD La 2012) (Allen Complaint). Regarding joint-authorship, Allen 'acknowledged that the court could find that Williams was the co-owner of the tattoo on Williams's left arm', despite the release form Williams had signed which vested the property of the artwork with Allen unless expressed otherwise. See Yolanda M. King, 'The Enforcement Challenges for Tattoo Copyrights' (2014) 22(1) J Intell. P L 29 at 40. The case was dismissed by mutual consent of the parties within the year.

71 Solid Oak Sketches v. 2K Games Inc, WL 4126543 (SD NY 2016).

72 Foad Consulting Group, Inc v. Azzalino, 270 F Supp (3d) 821 (9th Cir 2001) at 832.

73 Christopher M. Newman, "What Exactly Are You Implying?": The Elusive Nature Of The Implied Copyright License' (2014) 32(2) Cardozo Arts \& Ent LJ 501 at 527.

74 Ibid at 528-29.

75 David Vaver, 'Copyright in Legal Documents' (1993) 31(4) Osgoode Hall LJ 661 at 670 .

76 In delineating the circumstances in which an implied license can be found in New York's Southern District, the court stated that 'courts in this Circuit have found an implied non-exclusive license "where one party created a work at the other's request and handed it over, intending that the other copy and distribute it"'. See Solid Oak Sketches LLC v. 2K Games, Inc, 2020 WL 1467394, F Supp (3d) (SD NY 2020) at 7. 
the tattooists necessarily granted the Players nonexclusive licenses to use the Tattoos as part of their likenesses'. ${ }^{77}$ Evidence given by the tattoo artists themselves established that:

(i) the Players each requested the creation of the Tattoos, (ii) the tattooists created the Tattoos and delivered them to the Players by inking the designs onto their skin, and (iii) the tattooists intended the Players to copy and distribute the Tattoos as elements of their likenesses, each knowing that the Players were likely to appear 'in public, on television, in commercials, or in other forms of media, ${ }^{78}$

The traditional magic circle would characterize video game copyright as an opt-in system. However, as gaming environments increasingly implement real world elements, achieving an astounding degree of realism, video game copyright continues to trend toward an opt-out system. Such a system hinders not only the personal autonomy of both user and developer, but also certainty in their transactions. The user becomes bound by a formal system to which they did not consent, and the developer's incentive to innovate is constrained by exposure to latent liability. In an expansive system of implied license shaped by the scope of consent between developer and user; autonomy, innovation, and certainty can all thrive. This may be the only way that copyright law can keep up with regulating video game technology, especially in online environments.

\subsection{The fair dealing and fair use exceptions}

One of the ways that the balancing of interests is upheld is by creating exceptions to copyright infringement. A significant and flexible example is the fair dealing exception. By granting robust exceptions to an otherwise exclusive right, Anglo-American copyright law has, perhaps inadvertently, already carved out a flexible iteration of the magic circle for certain uses of artistic works. Fair dealing gives a free pass to works that would otherwise amount to an infringement when used 'for the purpose of research, private study, education, parody or satire' ${ }^{79}$ Fairness is not defined by the Copyright Act. Instead, it is assessed on a case-by-case basis. The Supreme Court of Canada has provided an analytical framework for what constitutes fair dealing by providing the following considerations: the purpose of the dealing; the character

77 Ibid.

78 Ibid.

79 Copyright Act, s 29.

80 CCH Canadian Ltd v. Law Society of Upper Canada, 2004 SCC 13 at para 12.

81 Michael Geist, The Copyright Pentalogy: How the Supreme Court of Canada Shook the Foundations of Canadian Copyright Law (University of Ottawa Press, 2013) iii. of the dealing; the amount of the dealing; alternatives to the dealing; the nature of the work; and the effect of the dealing on the work. ${ }^{80}$ In 2012, a pentalogy of Canadian copyright cases expanded what constitutes fair dealing by providing an 'unequivocal affirmation that copyright exceptions such as fair dealing should be treated as users' rights', ${ }^{81}$ thereby extending users' rights and broadening the scope of the public domain. The American equivalent to fair dealing is known as fair use. In response to the initial 2016 lawsuit, the defendants in Solid Oak Sketches counterclaimed, arguing that the disputed tattoos constituted fair use. Akin to fair dealing, fair use is assessed on a case-specific basis. With the parties unwilling to settle, Solid Oak Sketches went to New York's Southern District Court to assess the merits of a fair use argument.

In exploring the purpose and character of an allegedly infringing use, American courts consider whether the impugned work simply supersedes the original creation's purpose, or rather adds a new aspect 'with a further purpose of a different character, altering the first with new expression, meaning, or message'. ${ }^{82}$ The analysis inquires whether the use is 'transformative' which: (1) compares the artworks' purposes to determine if they are different; and (2) assesses the size of the reproductions; and ascertains: (1) whether the reproduction has detracted from the expressive value of the original, and (2) the proportion of material that was copied.

In applying the analysis in Solid Oak Sketches, the court first found the use of the tattoos to be transformative. The uncontroverted evidence revealed that the purpose for the tattoos appearing in the games was different than the purpose for which the tattoos were originally created. Including the tattoos in the games was to enhance the 'general recognizability of game figures as depictions of the Players' ${ }^{83}$ Second, the size of the in-game tattoos appeared 'at $4.4 \%$ to $10.96 \%$ of their actual size' which hindered their observability. ${ }^{84}$ Third, the court found that the NBA $2 \mathrm{~K}$ games minimized the expressive value of the tattoos. The images were observable only infrequently and imprecisely and were 'combined with myriad other auditory and visual elements' ${ }^{85}$ Fourth, the tattoos only formed an inconsequential portion of the games, accounting for a very small fraction of the game data. Finally, while the games did have a commercial purpose,

82 Bill Graham Archives v. Dorling Kindersley Ltd, 448 F Supp (3d) 605 (2nd Cir 2006) at 608

83 Solid Oak Sketches (fn 76) at 8 .

84 Ibid.

85 Ibid at 9 . 
the fact that the tattoos were indistinguishable during gameplay, combined with the fact that they did not appear in any marketing materials militated in favour of finding that the tattoos were incidental to the games' commercial value.

With regard to the nature of the work, the plaintiff had conceded that the tattoos had been previously published. Additionally, the court found the tattoos 'more factual than expressive because they are each based on another factual work or comprise representational renderings of common objects and motifs that are frequently found in tattoos' ${ }^{86}$ Testimony from tattooists also revealed that none of the tattoos were 'based on unique or expressive features' ${ }^{87}$ Rather, they copied common tattoo motifs or replicated existing designs.

In quantifying the amount of the use, the court found that the undisputed evidence demonstrated that although 'the Tattoos were copied in their entirety, Defendants did so in order to effectuate the transformative purpose of creating a realistic game experience' ${ }^{88}$ In other words, to further close the divide between the real and virtual world. However, as technology continues to evolve, game graphics will become less like 'visual noise' (a term that was used to characterize the tattoos relative to the rest of the game's interactive environment). Graphics improve rapidly, so the analysis used in Solid Oak Sketches may not apply to a modern game with improved graphics which displays a tattoo with perfect clarity.

Fair use also considers how the reproduced work affects the existing or potential market for the original work, or its value. This factor inquires whether the copy replaces the original with a competing substitute on the market, 'so as to deprive the rights holder of significant revenues because of the likelihood that potential purchasers may opt to acquire the copy' instead of the original. ${ }^{89}$ Since the court had already found the ingame versions of the tattoos to be transformative, by definition they were not substitutions for the original work. In any event, the plaintiff expressly conceded that 'NBA $2 \mathrm{~K}$ is not a substitute' for the original tattoos, which precluded a finding of economic harm. ${ }^{90}$ Finally,

89 Authors Guild v. Google, Inc, 804 F Supp (3d) 202 (2nd Cir 2015) at 223.

90 Solid Oak Sketches (fn 76) at 10

91 Ibid at 11.

92 2K Games sought the expert opinion of Dr. Nina Jablonski, an anthropology professor "who has been researching the evolution and cultural meaning of human skin for 30 years' and the author of Skin: A Natural History. The defendants also sought the expertise of Dr. Ian Bogost, a professor of interactive computing and business. Dr. Bogost is 'a key figure in the field of video game studies and ... has authored over 200 journal publications, the court held that the tattoos featured in the games constituted fair use, and found in favour of the defendants.

The balancing of interests in Solid Oak Sketches was unique. Since all four of the fair use factors weighed in favour of the defendants, the court did not struggle to find balance. However, the reasoning involved a unique weighing of interests: an exclusive license holder against the right of publicity held by professional basketball players. The court concluded that even if a market for licensing tattoos for use in video games or other forms of media were feasible, the plaintiff would be precluded from capitalizing on such a market because they were 'not licensed to use the Players' publicity rights'. ${ }^{91} \mathrm{Had}$ the plaintiff succeeded, the decision may have initiated a market for licensing tattoos in video games by incentivizing litigation for economic-based copyright infringement claims. Additionally, a contrary decision may have created latent liability for developers who create a realistic depiction of someone's likeness, even if that person does not own the copyright in a particular aspect of that likeness. However, the correct result was achieved at least partially because of input from community experts whose evidence implicitly cautioned against a resolution that would favour a litigious license holder.

\subsection{Reliance on community expertise}

Interestingly, the Solid Oak Sketches court relied heavily on expert evidence adduced by the defendants and testimony from tattooists to gain an understanding of nuanced aspects of tattoo and video game cultures. ${ }^{92}$ In dismissing the plaintiff's motion to exclude the experts' testimony, the court discussed the probative value of their evidence. Two of the experts were respected members within their respective communities of tattoo art and video games. Dr. Jablonski offered a robust explanation 'on the use of tattoos as a means of personal expression, about customs and norms within the tattoo industry (including between tattooist and client), and the unlikelihood that a market for licensing tattoos will develop' ${ }^{93}$ Dr. Bogost opined about video game industry factors and submitted that the development of a articles, book chapters, and conference papers on video games and digital culture'. Ibid at 13 .

93 Ibid at 12 . Widely accepted standards within the tattoo industry acknowledge that often tattoos will need to be altered or 'touched-up' by artists other than the original designer. If copyright claims could be based on modifying initial works, especially with bodily autonomy underlying the personal nature of a tattoo, the floodgates would open to industry-discordant claims. Artists give bearers of their work significant latitude with respect to users' rights: Recognizing 'public displays of their tattoos, ... clients' rights to re-produce images of their tattooed bodies, whether by uploading images to their Facebook profiles, submitting photos for publication in tattoo magazines, or even reproducing a picture of the tattoo for commercial purposes'. See Aaron Perzanowski, 'Tattoos \& IP Norms' (2013) 98(2) Minnesota L Rev 511 at 537. This is 
market for licensing copyright in that industry was unlikely.

At least in terms of their origins, tattoo art and video games are subcultures. Defining unusual canvasses as 'subcultures' properly reflects their purpose: to remain subterranean, left underground to self-regulate until conventional regulatory frameworks can properly frame their unusual locations and modes of expression. Once they do emerge in the mainstream by transcending their insular existence, subcultures interact with the law in a strange way. These strange interactions cannot be evaluated effectively by the traditional actors of formal legal systems without unduly burdening the current system. To the extent that unusual forms of artistic expression are animated by their confounding relationship with traditional laws, these canvasses, their cultural ecosystems, and their community norms should receive the type of deference they did in Solid Oak Sketches. Any subcultural community that binds itself by rules that come from a sense of consensual play or interaction is competent to set customs that are worthy of the law's remedial capacity. An approach that acknowledges and understands the inherent interactivity of these artforms is especially important when disputes require an evaluation of a work's integrity.

\section{Moral rights and video game modifications}

Historically, moral rights come from the civil law tradition, but are now enshrined in the Berne Convention for the Protection of Literary and Artistic Works. ${ }^{94}$ Moral rights treat an artist's work as an extension of their personality, and acknowledge an inherent dignity that

reflected in the tattoo copyright cases that have arisen thus far. Copyright infringement claims in this context seem to arise within highly lucrative deals with third parties that either prominently display the artwork, or use it in a way that does not accord with prevailing industry norms. Tattoo artists make a unique distinction between the use of the tattoo when attached to the body, and use of the underlying design 'as a work disconnected from the body, which are subject to greater skepticism'. Ibid. This ultimately reduces issues of licensing or fair dealing to hinge on the identity of the bearer.

94 Berne Convention for the Protection of Literary and Artistic Works, Art 6bis, 24 July 1971, as amended on 28 September 1979, S Treaty Doc No 99-27.

95 Copyright Act, s 14.1

96 Ibid, s 14.1(2).

97 Carter v. Helmsley-Spear Inc., 71 F Supp (3d) 77 (2nd Cir 1996).

9817 USCA $\$ 106 \mathrm{~A}(3)$ (2000). The language of this provision recently came under the scrutiny of the US Second Circuit Court of Appeals in Castillo $v$. G»M Realty LP, 950 F Supp (3d) 155 (2nd Cir 2020). Known colloquially as 'the 5Pointz litigation', the case involved a group of street artists who sought injunctive relief against the defendant for attempting to demolish derelict warehouse buildings that he owned. However, these were no ordinary buildings. They were the site of the famous 5Pointz, a New York City art space that developed great cultural significance after 2002. The defendant, Gerald Wolkoff, facilitated this transformation by opening deserves protection. Rather than focusing on appropriation, moral rights protect the integrity of the work. ${ }^{95} \mathrm{~A}$ successful claim for infringement of moral rights does not allow plaintiffs to claim damages, but instead provides injunctive relief. As part of copyright ownership, moral rights crystallize at the point of expression. Unlike licensing, they cannot be assigned - only extinguished by waiver. ${ }^{96}$ Contrary to its American counterpart, the Canadian Copyright Act provides robust protection of moral rights. US court decisions have generally remained hostile toward expanding artists' moral rights. ${ }^{97}$ For example, the American Visual Artists Rights Act only extends moral rights narrowly to works 'of recognized stature..$^{98}$

Snow v. Eaton Centre $L t d^{99}$ was the first Canadian case to significantly consider moral rights. In that case, 'a sculptor objected to the Eaton Centre festooning with Christmas ribbons his creation of a flight of 60 Canada geese that are forever poised to land inside the south entrance of a downtown shopping mall in Toronto'. ${ }^{100}$ According to the sculptor's lawyer, he was 'adamant in his belief that his naturalistic composition has been made to look ridiculous by the addition of ribbons and suggests it is not unlike dangling earrings from the Venus de Milo'. ${ }^{101}$ Such an impassioned claim against Christmas decorations could only be remedied by an injunction, as the sculptor was concerned not with money, but with his reputation. So despite the fact that the flying geese had been bought and paid for, 'the artist was able to reach across the ownership divide to take action against a successor owner not for infringing his economic rights but for violating his moral rights'. ${ }^{102}$ The judge agreed that the artistic integrity of the geese had been compromised, and granted the injunction.

up the space to graffiti artists. After he put one of the plaintiffs, Jonathan Cohen in charge of the buildings, Cohen began renting the space to other artists. During his decade as site curator, Cohen had 'established a system of rules for both the creation and curation of the art, spending seven days a week without pay to bring 5 Pointz to fruition. ... Over time, crime in the neighborhood dropped and the site become a major attraction drawing thousands of daily visitors, including busloads of tourists, school trips, and weddings. ... [I]t was used for the 2013 motion picture Now You See $\mathrm{Me}$, starring Jesse Eisenberg and Mark Ruffalo, and was the site of a notable tour for R\&B singer Usher'. See Cohen $v$. G \& $M$ Realty $L P$, WL 1182712 (ED NY 2015) at 15. However, during the litigation, Wolkoff whitewashed the artworks before a decision was rendered. The court of first instance found this to be a violation of the Visual Artists Rights Act, and awarded the plaintiffs statutory damages of $\$ 6.75$ million for significantly damaging the artists' careers and loss of future income. In upholding the colossal damages award, the Second Circuit held that

'a work is of recognized stature when it is one of high quality, status, or caliber that has been acknowledged as such by a relevant community'. See Castillo (fn 98) at 166 [emphasis added].

99 Snow v. Eaton Centre Ltd, [1982] OJ No 3645.

100 Théberge (fn 8) at para 17.

101 Ibid.

102 Ibid at para 18. 
The proliferation of gaming modifications, or 'mods' for short, has correlated with the expansion of the industry generally. Consalvo views the departure of game worlds from their developers hands to be 'taken up (and altered, bent, modified, extended) by players or users' as an inevitability. ${ }^{103}$ The practice of modifying a game's source code has been permitted and even facilitated by game developers since the 1990s, with the scope of permission defined by End User License Agreements. ${ }^{104}$ Especially popular mods are even construed as an enhancement or supplement to the original game. ${ }^{105}$ Given that mods are created by altering a game's source code, determining authorship for the purposes of copyright can become ambiguous. This is especially so when a mod involves a complete overhaul of the game's content (known as a 'total conversion') that runs on the same software architecture. ${ }^{106}$ This issue is easily resolved when a developer facilitates modifications within the game, or simply adopts or endorses a popular mod, but less so when a more extensive mod is perceived as an affront to a game's design. Early copyright infringement claims directed at mods seemed to operate on developer-centric presumptions, finding copyright infringement almost as a matter of course. One such example was MDY Industries, LLC v. Blizzard Entertainment, Inc, ${ }^{107}$ an Arizona case which held that a mod that allowed players' characters to move automatically in World of Warcraft infringed upon the developer's copyright. The court's reasoning was based on a case from the early 1990s which held that copying a computer program into RAM amounted to copyright infringement.

A more clear-cut case might be found where modifications are made not to a game's appearance and gameplay, but to its payment structure. This was precisely what happened in a different World of Warcraft case. In Blizzard Entertainment, Inc $v$. Reeves, ${ }^{108}$ the defendant, Reeves along with her colleagues at Scapegaming used legally purchased copies of the game and reverse engineered the code, allowing users to play the game for free on private servers. Blizzard Entertainment brought a claim for statutory damages under the US Digital Millennium Copyright Act. ${ }^{109}$ The provision that Blizzard relied upon prohibits users from circumventing technological copyright protection systems. ${ }^{110}$ However, in a strange and contradictory turn of events, the court acknowledged that Reeves had not sold 'products that themselves violate the Digital Millennium Copyright Act by allowing users to circumvent the Plaintiff's protective measures. Rather, Defendant is selling products that enhance users' gaming experiences while infringing Plaintiff's copyrights'. ${ }^{111}$ Yet, because Reeves never responded to the claim, the court proceeded ex parte and awarded Blizzard a default judgment of $\$ 88$ million, which included statutory damages under the DMCA. ${ }^{112}$

It is interesting that the court recognized Reeves' modification enhanced the users' gaming experience (although most would likely agree that not having to pay a monthly fee is an enhancement), but ruled in a seemingly punitive manner regardless. The court was surprisingly candid in this regard, stating that although the 'Defendant's sales of in-game items and services probably violates some statute, it does not violate the statute under which Plaintiff seeks statutory damages ... That said, the Court is sympathetic to the potential difficulty Plaintiff faces in calculating the number of "acts of circumvention" performed on the Defendant's servers'. ${ }^{113}$ Perhaps if Reeves had shown up for trial, it would have changed the course of how US copyright law frames modding. Altering a game such that it diverts profits from the developer will almost certainly invite litigation, but softer changes that attain widespread community approval may be considered derivative works that will not motivate developers to claim copyright infringement.

Some commentators advocate for the proposition that certain mods ought to be treated as derivative works. Megan Carriker, a video game industry veteran writing for Odin Law and Media, is one such commentator. Carriker explains copyright law's treatment of mods in the following way: 'Creating a game mod is similar to going into an art gallery, pulling a painting off the wall, and putting a painting inside of the painting. You own what you created but your creation is infringing
103 Consalvo (fn 28) at 411.

104 Jon Festinger, Chris Metcalfe and Roch Ripley, Video Game Law, 2nd edn (LexisNexis, 2012) 88.

105 In Los Santos, the online cityscape of Grand Theft Auto V, Rockstar Games allows users to design their own jobs (which include various missions such as races and deathmatches) using its Content Creator. Rockstar tests user-created jobs that attain a certain level of popularity, and handpicks those deemed to be worthy of being 'Rockstar Verified'. Verified jobs are then published by Rockstar and become available to the entire community. Each job has a popularity ranking based on user input, and sometimes Verified jobs outrank those created by Rockstar.
106 Note, 'Spare the Mod: In Support of Total-Conversion Modified Video Games' (2012) 125(3) Harv L Rev 789 at 789.

107 MDY Industries, LLC v. Blizzard Entertainment, Inc, 616 F Supp (2d) 958, 970 (D Ariz Loc R 2009).

108 Blizzard Entertainment, Inc v. Reeves, 2010 WL 4054095 (CD Cal, 2010). 10917 USC $\$ 1203(1)(2010)$ (DMCA).

11017 USC $\$ 1203(\mathrm{c})(3)(\mathrm{A})$.

111 Blizzard (fn 108) at 2 [emphasis added].

112 Ibid at 4 .

113 Ibid at 2-3 [emphasis in original]. 
on the original artist's copyright to do it unless they've given you the right to do it'. ${ }^{114}$ Recall that Second Life allows users to retain copyright in their in-game creations. Most of the industry now takes this approach to mods, albeit unofficially. This is due to the financial incentive behind permitting a popular mod to flourish it attracts more users. However, unlike Linden Lab, most developers are loath to entirely relinquish their copyright as it may result in servers becoming overloaded with user-generated content. With online worlds that continuously provide users more freedom, copyright may be the only tool at a developer's disposal to maintain control over their creation and its profitability.

Some game modifiers have adopted the 'easier to ask for forgiveness than permission' or 'catch me if you can' philosophies. However, such defiance has become largely unnecessary, since most developers have largely realized the financial benefits of mods. ${ }^{115}$ The archetypal example of this is Counter-Strike, an online first-person shooter with a devoted following, which was initially created as a mod for Valve's Half-Life. Counter-Strike came to be considered 'the best tactical-shooter game ever made'. ${ }^{116}$ Mods can have a practical function without going as far as changing the game's essence. For example, unofficial repairs to a game that suffers from bugs, graphical glitches, or poor performance are known as restorative game patches. Michael Fiorido posits that once game developers will no longer fix these issues, unofficial game patches are 'amazing examples ... of the dedication and ingenuity that modders bring' to a game. ${ }^{117}$ For a developer to characterize a restorative game patch as copyright infringement would be to look a gift horse the mouth. It would be foolish to turn down free mechanical work.

Not all mods have such a positive effect on the games upon which they are based. One such example was the 'Hot Coffee' mod in Rockstar Games' Grand Theft Auto: San Andreas. Rockstar had originally included code for a mini-game wherein the main character could have sex with his girlfriend, which was later abandoned. ${ }^{118} \mathrm{~A}$ savvy player located the code which had been included in the final issue of the game and modified it, allowing players to regain access to the mini-game. After initially attributing authorship to the player, Rockstar eventually owned that they had authored the mini-game, which led to grave financial consequences: the Entertainment

114 Megan Carriker, 'Who Owns My Game Mod?', Odin Law and Medi (blog), available at: https://odinlaw.com/who-owns-my-game-mod/.

115 Spare the Mod (fn 106) at 792.

116 Michael Fiorido, 'Moral Rights and Mods: Protecting Integrity Rights in Video Games' (2013) 46(3) UBC L Rev 739 at para 9.

117 Ibid at para 17.
Software Rating Board upped the game's rating from 'Mature' to 'Adults Only', which 'caused many major retailers to pull the game from their stores'. ${ }^{119}$

Given that the Canadian Copyright Act protects an artists' moral right to the integrity of their work, and provides that this right is engaged when an artistic work is 'distorted, mutilated or otherwise modified', 120 it may seem that video game mods would be an attractive target for a moral rights claim. Fiorido advocates for such an approach, ${ }^{121}$ and Guadamuz claims that 'something akin to moral rights' could be invoked to 'help businesses and individuals safeguard their data' from being widely distributed as the subject of user-generated content. ${ }^{122}$ However, redress is limited for moral rights claims. In the context of mods, if a Canadian developer invoked their moral rights, they would have to pursue injunctive relief. Such a prohibitive step could be seen as a betrayal to their game's followers which would stifle the mod's potential to enhance a game's popularity and resulting revenue.

As Solid Oak Sketches reveals, nuanced considerations apply when the issues inherent to unusual canvasses give rise to the implied license and fair dealing defences. The same goes for moral rights considerations that require a work's integrity to be evaluated. When it comes to unusual artforms, such analyses require specific expertise. To borrow from the constitutional law principle of subsidiarity, those closest to an issue should be the decision-makers with regard to that issue; logically, they are most familiar with it. In the balancing act between developer and user, the communities who regularly play at the vanguard between real and virtual worlds are the only ones sufficiently qualified to assess when balance has been achieved.

\section{A balancing act between the public domain and creative individuals}

Anglo-American legal frameworks view copyright as necessary to inspire innovation. But this interpretation of copyright also reflects the classic dilemma of the tragedy of the commons. If the scope of the public domain is too broad, creators may lose the inspiration to create without assurances against piracy or appropriation. On the other hand, too much private property has the effect

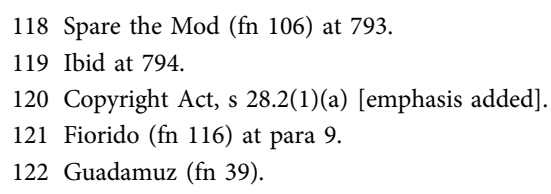


of stifling creativity. A prime example of this is Stephen Joyce, grandson of author James Joyce, who has fought vehemently to prevent the use of his grandfather's work. ${ }^{123}$

The 2002 case of Théberge v. Galerie d'Art du Petit Champlain Inc $^{124}$ marked a major turning point in Canadian copyright law. This case laid the foundation for a pentalogy of cases that arose a decade later which expanded Canadian copyright law beyond its traditional bounds, aligning it more closely with the US and progressive international treaties. In Théberge, Mr. Justice Binnie stated that it is desirable, ... to harmonize our interpretation of copyright protection with other likeminded jurisdictions' ${ }^{125}$ In this harmonizing process, the court adopted several international copyright principles. First, the court defined the purpose of copyright as a balance of interests. On one hand, the court considers the individual rights of the creator in maximizing the monetary benefits from their creation. On the other is consideration of the public interest in 'the encouragement and dissemination of works of the arts and intellect'. ${ }^{126}$ Second, the court acknowledged the need for a public domain.

The public domain is circumscribed by the extent of users' rights. When works exist in the public domain, creativity is maximized by ensuring that legal constraints on creativity are minimized. This also allows the law to remain dynamic, and thus adaptable to developing technologies or cultural norms. An accessible public domain is achieved by striking the proper balance of interests to

123 The controversy around Joyce's work may have finally come to an end. Stephen Joyce, the 'stubborn literary executor' of James Joyce's estate is now dead. See B.D. McClay, 'James Joyce's grandson and the death of the stubborn literary executor', The Outline (27 January 2020), available at: https://theoutline.com/post/8603/stephen-joyce-james-joyce-literaryestate?zd=1\&zi=uqfkper6. This protectiveness has also arisen amongst musicians whose songs have been used without their permission for political events, such as the Rolling Stones objecting to the use of their music by Donald Trump. See Luke O’Neil, 'Can't always get what you want: why artists struggle to stop politicians using their songs', The Guardian (30 October 2018), available at: https://www.theguardian.com/us-news/ 2018/oct/30/pharrell-trump-music-politicians-bands-cease-desist.

124 Théberge (fn 8).

125 Ibid at para 6 .

126 Ibid at para 30.

127 Arturo Di Modica is an Italian sculptor who lived in New York City during the late 1980s. In December 1989, Di Modica, with a little help from his friends, but without permission, dropped off a large sculpture in a public space 'near the New York Stock Exchange as a symbol of hope' after the market crash of 1987. See Dorit Samuel, 'Intellectual Property Valuation: A Finance Perspective' (2007) 70(4) Albany L Rev at 1217. The 'Charging Bull' sculpture remains a famous landmark of Wall Street to this day. Di Modica would eventually register the sculpture with the US Copyright Office in 1998. Ibid at 1218. After a failed attempt at selling it, Di Modica opted to give 'Charging Bull' to the people of New York as a Christmas gift, 'but the cops said it was illegal'. See Kati Cornell Smith, 'Artist "Bull” Fight - Copyright Charge', New York Post (22 September 2006), available at: https://nypost.com/2006/09/22/artist-bull-fight-copyrightcharge/. Fast forward to 2006, Di Modica names 12 defendants in a ensure that copyright holders do not monopolize control over artistic works. ${ }^{127}$ Effective balancing by the courts seeks to avoid a desolate creative commons which would effectively privilege certain types of works over others. In her book Copyright Beyond Law: Regulating Creativity in the Graffiti Subculture, Marta Iljadica argues that intellectual property law's 'inability ... to accommodate and protect collective forms of creativity $^{128}$ has led to an inevitable and inescapable privileging of certain artforms, much to the chagrin of other cultures. In response, certain subcultures have developed their own internal self-regulating systems, ${ }^{129}$ or 'bounded commons' that effectively foster individual creativity while maintaining productivity within a nonprivileged community.

Massive multiplayer online game worlds exemplify such consent-based community systems. When developers permit users to interact with the environments they create, the sense of play that evolves between thousands of users can recast the entire environment. With enough users, these worlds become unusual canvasses with complex social structures. One example is the astonishingly vast user-generated universe of CCP Games' Eve Online. ${ }^{130}$ Progress within this fascinating universe requires immense dedication, which has caused it to attract a massive cult following from government wonks to hedge fund managers. These users form giant corporations within the game that seek to dominate outer space. ${ }^{131}$ Consequently, its largely player-driven economy has significant real-life implications. One battle

copyright infringement lawsuit after discovering that Wal-Mart was selling framed photos of his then famous sculpture. See Di Modica v. North Fork Bancorporation, Inc, No 6 Civ 7210 (SD NY 2006). Di Modica angrily claimed that such a use was 'not a good representation of my work. It's destroying my image'. See Cornell Smith (fn 127). If Di Modica had the motivation to claim copyright infringement over this use of his sculpture, one might wonder how he would react if the 'Charging Bull' became a Pokéstop.

128 Marta Iljadica, Copyright Beyond Law: Regulating Creativity in the Graffiti Subculture (Hart Publishing, 2016) 46.

129 These are reminiscent of the system among stand-up comedians. Since there is no copyright in a joke, the story goes that if you steal someone else's joke without their permission and get called on it, the joke pirate is faced with a choice: They can pay the claimant $\$ 100$, or get punched in the face.

130 A video that forms part of Eve Online's MoMA exhibit conveys the sheer enormity of the game's universe. It is inhabited by players from all over the world, contains over 67,253 planets in 7,929 solar systems, and is intersected by a network of wormholes. Players can 'participate in a number of in-game professions and activities, including mining, piracy, manufacturing, trading, exploration, and combat'. See video available at: https://www. youtube.com/watch?v=EGuDUbZIo_o. According to forum discussions, crossing the universe at its widest point takes approximately 220 hours. See Eve General Discussion Forum Index, available at: https://forumsarchive.eveonline.com/message/58784/.

131 Ashlee Vance, 'Multiplayer Game "Eve Online" Cultivates a Most Devoted Following', Bloomberg News (18 April 2013), available at: https://www. bloomberg.com/news/articles/2013-04-18/multiplayer-game-eve-onlinecultivates-a-most-devoted-following 
involving over 7,500 participants, each with their own discreet set of contributory tasks, lasted 21 hours and 'cost up to $\$ 330,000$ in real-life currency'. ${ }^{132} \mathrm{CCP}$ Games described it as 'gaming's most destructive battle ever'. ${ }^{133}$

New York's Museum of Modern Art has established a permanent exhibit for Eve Online, the gallery label for which reads: 'CCP Games has created a complete experience, employing not only designers and developers but also economists and anthropologists. CCP explains that the "power [belongs] to the players. Nothing compares to a player that is enabled to affect the universe."'134 When an author allows users to collectively contribute to a game's permanent appearance, power dynamics, and lore, the ripple effect is felt beyond the virtual world. Such an effect further blurs the line between the public and private spheres, complicates the already difficult balancing act between the rights of users and creators, and brings into question whether the magic circle still exists in video games. Video games have become a commercial juggernaut ${ }^{135}$ featuring in-game currency with significant real-world value. ${ }^{136}$ Although exchanging Eve Online's in-game currency for real money is against Eve Online's terms of service, ${ }^{137}$ its real-world value is undeniable, which evidently leads to noncompliance. ${ }^{138}$

\section{The magic circle, redrawn: a framework for shared spaces}

For an unusual artform, the video game industry is incredibly lucrative. Some estimates value it at $\$ 120$ billion globally. ${ }^{139}$ As seen in Solid Oak Sketches, claimants tend to become more litigious when they detect deep pockets. When their disputes came to have significant financial consequences, video games left the playground behind. The magic circle's traditional principles did not survive

132 Jenna Pitcher, 'Eve Online's Bloodbath of B-R5RB cost up to $\$ 330,000$ ', Vox Media: Polygon Gaming News (30 January 2014), available at: https://www.polygon.com/2014/1/30/5360208/Eve-Onlines-Bloodbath.

133 C.C.P. Dolan, 'The Bloodbath of B-R5RB, Gaming's Most Destructive Battle Ever', Eve Online Developer Blog (1 February 2014), available at: https:// www.eveonline.com/article/the-bloodbath-of-b-r5rb.

134 MoMA Gallery Label (fn 50).

135 The prime example of this is the revenue Grand Theft Auto V has generated for Rockstar Games. Since its 2013 release, the game has sold 110 million copies. These sales have generated a staggering revenue of over \$6 Billion, gaining it the sweeping attribute of 'most profitable entertainment product in history'. See Erik Kain, 'Putting Grand Theft Auto V's 110 Million Copies Sold Into Context', Forbes Magazine (14 May 2019), available at: https:// www.forbes.com/sites/erikkain/2019/05/14/putting-grand-theft-auto-vs110-million-copies-sold-into-context/\#794469712cac.

136 Video game designer Ted Brown, who is also an Eve fanatic, described Eve Online as 'part game and part soap opera and part shadow economy'. See Vance (fn 131). With enough participants, shadow economies eventually come to mirror, and even influence existing economies. the video game industry's transformation into a commercial juggernaut. In the evolution from store-bought software to free-to-play games that profit from microtransactions, the magic circle faded away. This model has created a top-down vertical relationship that secured developers' control over their games, but undermined the magic circle's utility as a framework in the process. However, if legal practicality is the goal, then the greater deference that can be given to community rules, the better. Consalvo claims that the magic circle 'emphasizes form at the cost of function, without attention to the context of actual gameplay. With contemporary games ... and [massive multiplayer online games] in particular, context is key, as many scholars have found'. ${ }^{140}$ Another omnipresent aspect of the magic circle is consent. Consent is also fundamental to copyright infringement analysis generally, and it can be express or implied 'through knowledge and conduct.'. ${ }^{141}$ By drawing on the consent that defines the customs of gaming communities, the magic circle can be redrawn in order for copyright law to keep track of where the ordinary world ends, and where the virtual one begins.

The traditional conception of the magic circle articulated a form of immunity from formal legal systems. However, it is actually more of a process. The process involves interactive play that is constantly redrawing the bounds of the magic circle, giving it a fluidity that does not accord with its traditional, structuralist conception. Consalvo characterizes it as 'a contextual, meaningmaking process' ${ }^{142}$ Constance Steinkuehler considers game developers and the communities that inhabit their worlds as 'two sets of agency in conversation with one another' in a mangle of play. ${ }^{143}$ Conceptualizing the magic circle instead as a communicative process acknowledges the inherent interactivity of modern gaming. Unusual canvasses that interact or play with the world beyond their subcultures are not immune to

137 Eve Community, Help \& Support: Policies, available at: https://commu nity.eveonline.com/support/policies/terms-of-service-en/.

138 One of Eve Online's more notorious scandals resulted in the collapse of EBank, the game's largest player-run financial institution. The bank's CEO embezzled 200 Billion ISK (Eve Online's currency), 'swapped them for real world cash of $£ 3,115 \ldots$ [and] used the cash to put down a deposit on a house and pay medical bills'. See 'Billions stolen in online robbery', BBC News (3 July 2009), available at: http://news.bbc.co.uk/2/hi/8132547. stm.

139 Kevin Webb, 'The $\$ 120$ billion gaming industry is going through more change than it ever has before, and everyone is trying to cash in', Business Insider (1 October 2019), available at: https://www.businessinsider.com/ video-game-industry-120-billion-future-innovation-2019-9.

140 Consalvo (fn 28) at 411.

141 Waldman v. Thompson Reuters Corp, 2012 ONSC 1138 at para 88.

142 Consalvo (fn 28) at 413.

143 Constance Steinkuehler, 'The Mangle of Play' (2006) 1(3) Games and Culture 199 at 211. 
outside influences. Gary Alan Fine suggests that game users interact with and respond to real world intrusions, negotiating a relationship that is continually in dynamic tension'. ${ }^{144}$ These users may still enjoy protection from some variant of the magic circle. As long as this variant is drawn by those who understand its limitations, creativity and innovation will thrive.

Video game law scholars such as Trey Hickman and Kristin E. Hickman consider the classic end user license agreement that appears prior to installing games as logically embodying a formal contract, but claim that 'the more important rules in a choice-based participatory environment are those generated by the society itself. ${ }^{145}$ Joshua Fairfield concurs, arguing that virtual worlds may 'generate community norms usable by real-world courts as a source of legal rules' and that end user license agreements already 'interact with community norms, individual consent, and background law to generate legal outcomes'. ${ }^{146}$ In this sense, unusual canvasses could benefit from the administrative law principle of judicial deference. When the subject matter of a dispute requires specialized expertise to resolve, who better to consult than those who have already designed an effective self-regulating system?

Deference to cultural or community customs is not a novel proposition. As Fairfield indicates:

industry customs and practices often create default legal rules that courts draw upon in regulating those industries. Through the law of contract, private agreements can have the force of law. The regular course of business often sets a legal standard. Even the rules of a game can have the force of law: bite your opponent in a boxing match or cheat in a Las Vegas poker game and legal consequences will follow. Punch someone in a boxing match, or bluff in a poker game, and all is well. ${ }^{147}$

144 Gary Alan Fine, Shared Fantasy: Role-playing Games as Social Worlds (University of Chicago Press, 1983) 200.

145 Trey Hickman and Kristin E. Hickman, 'The Myth of the Magic Circle: Rejecting a Single Governance Model' (2012) 2(2) UC Irvine L Rev 537 at 554. Indeed, end user license agreements are not as binding as they may seem, especially for minors. In a recent class action launched against Epic Games, the developer of the wildly popular Fortnite, the representative plaintiff was a minor who claimed to have been targeted by predatory, non-refundable in-App purchases called 'loot boxes'. Under the contractual doctrine of disaffirmance, a US District Court in Northern California held that an arbitration clause in the end user license agreement did not apply to the plaintiff. The plaintiff had sent a letter of intent to repudiate the binding force and effect of the contract. The Court found that 'a minor's right to disaffirm a contract is broad and can be invoked through "any act or declaration" that conveys his intent to repudiate a contract'. See Johnny Doe v. Epic Games Inc, 2020 WL 376573.

146 Fairfield (fn 53) at 825,834

147 Ibid at 830 .

148 In the Netherlands, a boy was charged and convicted of violent theft after using real world threats to extort virtual items in the game Runescape. The accused and an accomplice 'used significant physical violence to persuade the victim (who was at the time 13 years old) to log into the game and drop the virtual objects' - a mask and an amulet. At issue was whether the in-game objects constituted 'goods' for the purposes of the violent theft provisions under Dutch criminal law. The case made it all the way
Many artistic subcultures have robust self-regulating systems that could provide sources of copyright law. Some of these cultures have a larger public domain than others. Perhaps this originates from creative pursuits with unmarketable beginnings or illegal methods. Interestingly, illegality may cause courts to encroach on the magic circle, ${ }^{148}$ but it does not preclude copyright protection. ${ }^{149}$ At first glance, the fact that illegal practices within graffiti subculture attract copyright protection might give the impression of a free-for-all, but such is not the case. The graffiti community regulates itself effectively: 'While letters are free for all to use, choices about the combination and style of letters, and where the final work is placed are circumscribed' within graffiti culture's intellectual commons. ${ }^{150}$ For the most part, tattoo artists and graffiti artists have shared in the choice to self-regulate their industry. Perhaps these subcultures are less sensitive about their work than the sculptor in Snow who took issue with festive decorations being added to his flock of geese. Or perhaps a more accurate explanation is that copyright law has often failed to frame these unconventional mediums, so that even if it applies to them, it has mostly been ignored. For example:

unlike their counterparts in most other creative industries, tattooers nearly uniformly reject formal legal mechanisms for adjudicating claims over ownership and copying. Although tattoos fall squarely within the protections of the Copyright Act, copyright law plays virtually no part in the day-to-day operation of the tattoo industry. Instead, tattooers rely on a set of informal social norms to structure creative production and mediate relationships within their industry. ${ }^{151}$

to the High Court, which upheld the conviction. See T. Van Der Linden, 'Stealing Masks and Amulets: What's Law Got to Do with it?' (2013) 46(3) UBC L Rev 665.

149 Tara Parker, 'Illegal Graffiti Capable of Copyright Protection' (2016) 35(34) The Lawyers Weekly: Focus on Intellectual Property, available at: https:// www.lexisnexis.ca/en-ca/products/the-lawyers-daily.page.

150 Iljadica (fn 128) at 2.

151 Perzanowski (fn 93) at 512-13. Perhaps the ultimate example of a tattooist rejecting formal law with an especially unusual canvas arose in 2006 when Belgian artist Wim Delvoye tattooed a man's back, then sold the 'work' for 150,000 Euros to German art collector Rik Reinking. In the past, Delvoye had tattooed pigs then framed their skin after they died - but never a human being. Entitled 'TIM', the tattoo is named after its bearer, Tim Steiner - the living canvas. In Tim's own words: 'My skin belongs to Rik Reinking now ... My back is the canvas, I am the temporary frame'. As part of his contract with Delvoye, Tim is to be posthumously skinned, but the tattoo will be framed permanently in Reinking's personal art collection. While Tim is still alive, he is contractually obligated to display the tattoo 'by sitting topless in a gallery at least three times a year'. In 2016, I had the pleasure of meeting Tim while working as an invigilator for the space around his exhibit at the Museum of Old and New Art (MONA) in Tasmania, Australia. All day, every day, Tim sat motionless on a plinth facing away from gallery patrons, thereby displaying Delvoye's infamous work. See Harry Low, 'The man who sold his back to an art dealer', BBC News (1 February 2017), available at: https://www.bbc. com/news/magazine-38601603. Delvoye's 'TIM' defies many formal legal 
In the realm of street art, this notion is aptly reflected by quoting its figurehead, Banksy: 'Copyright is for losers'. ${ }^{152}$ Taken on its own, this statement implies that street artists do not consent to copyright law's regulation. However, not all street artists shun copyright principles entirely. Graffiti subculture employs a 'bounded commons' to regulate creative constraints within the community, which also overlaps with the larger public domain. This bounded commons may be defined as 'a regime that is bounded by property rights but creates a type of limited public domain (or commons) within its boundaries' ${ }^{153}$ This allows graffiti artists to incentivize production within their community while 'seeking to enforce rights against those outside of the group. Indeed, graffiti writers have particular expectations about how non-writers use and share their work. ... For example, the letters of the alphabet are free for everyone to use, but a name will belong to a particular writer'. ${ }^{154}$

This issue arose in the case of Reece v. Marc Ecko Unltd, where a famous New York graffiti artist named 'Dip' had registered copyright for some of his designs. ${ }^{155}$ The defendants developed a graffiti-based video game called Getting Up: Contents Under Pressure, and used Dip's likeness and artistic designs in the game without his consent. The court held that the names 'Dip' and 'Dipism' were not subject to copyright protection, and that the artwork used in the game was insufficiently similar to uphold the claim. ${ }^{156}$ The original work, registered by the plaintiff, Reece, had used upper case lettering, and hyphenated Dip-ism, whereas the game used lowercase lettering, and a heart to dot the lowercase ' $i$ '. These differences rendered 'the overall effect of the Game work more whimsical'. ${ }^{157}$ Perhaps this whimsical depiction of the Dip name was precisely what motivated Reece to launch the claim, after being accustomed to respected limits within the bounded commons of the graffiti community.

All contemporary online gaming environments require support infrastructure. In keeping with administrative law as a prescriptive influence, support teams already delineate between mods and intended game content; they could also be consulted to interpret ingame custom. Terms of use, license agreements, and

rules: First, a living human body is incapable of being owned. See JCM $v$. ANA, 2012 BCSC 584. Accordingly, a person does not possess their body or any part of it. See $R v$. Bentham [2005] 1 WLR 1057 (HL). Since our body parts cannot be our own property, they cannot be the property of others, which applies to both living tissue and corpses. See Doodeward $v$. Spence [1908] 6 CLR 406. Finally, copyright cannot subsist in a real person, whether dead or alive. See Maltz v. Witterick, 2016 FC 524 at para 40. For now however, it appears that Tim Steiner's bodily autonomy has joined forces with freedom of contract to overtly contradict these rules while perfectly manifesting the odd relationship between copyright law and unusual canvasses. community norms could act as guidelines that inform interpretations of the game's internal system when formal legal systems are engaged. This would respect the integrity of existing self-regulating systems, and limit court intervention to only the most egregious cases of infringement. In other words, when a court considers that a user's behaviour has breached the magic circle that is, exceeded the scope of users' consent - that would give rise to an actionable dispute. Due to their extensive interactivity, modern video games allow users to manipulate the magic circle's parameters. In doing so, they also manipulate the law of shared spaces. Without buy-in from the communities that inhabit these spaces, formal systems of copyright law will only become further estranged from artworks that, while unusual, are deserving of our attention and respect. Such an outcome would betray the wellestablished inclusive benchmark that copyright seeks to uphold.

Self-regulating systems are not limitless in their generosity for users' rights. While it may appear that subcultural regulatory systems have covered the field for many uses of their works, some negative space remains. As the technological evolution continues to push the divergence of real and virtual worlds, the voids of negative space that appear between these worlds should not be filled by rules that operate to the exclusion of others. Rather, the magic circle should be redrawn to resemble a symbiotic relationship - a yin-yang of formal and informal systems with communities serving as intermediary between creator and user.

\section{Conclusion}

Every expression makes a statement. Copyrightable artistic works are an expression of an artistic idea. Online video game landscapes express the idea that users can influence each other's environment, such that community members create a dynamic gameplay experience for one another. The unique interactivity between online gaming environments and the wider world creates an incompatible relationship that itself makes a statement: singularity is approaching, and it is

152 Banksy, Wall and Piece, 1st edn (Century, The Random House, 2005).

153 Fiona Macmillan, 'Altering the Contours of the Public Domain' in C. Waelde and H. MacQueen (eds), Intellectual Property: The Many Faces of the Public Domain (Edward Elgar, 2007) 106.

154 Iljadica (fn 128) at 50.

155 Reece v. Marc Ecko Unltd, WL 4112071 (SD NY 2011).

156 Ibid at 13

157 Ibid. 
at odds with copyright law's current framework. Sharing community knowledge enhances our understanding of one another and reduces friction between cultures. We construct houses of art to manifest this cohesion. Walls are to a museum as clothes are to the body. They mediate the divide between the public and private domains. In the context of video games, terms of use and disclaimers clothe their online environments, but clothing is interchangeable. The world becomes a much more interesting place when we unbox unusual canvasses. Legal frameworks should thus be flexible enough for such canvasses to display their artwork in its completely expressed form.

Churches and museums were the traditional houses of art, where works were secure, and control was maintained. Modern art has become much more difficult to moderate. Online gaming environments have blurred the bounds of private and public domain. As creativity blossoms before the public eye, traditional legal rules have struggled to frame unusual canvasses. The result is a copyright framework that privileges artforms which neatly fit within existing limits, at the expense of innovation. This relationship raises questions about whether unusual canvasses reflect the law's full potential, or whether it is failing to do them justice by unduly constraining their creative expression. Anglo-American copyright law has fostered flexibility with the intention to welcome new artforms as they emerge. Whether this flexibility will be enough to accommodate unusual canvasses express remains uncertain. Some pursuits may be left to proceed by self-regulation, shunned by unfriendly markets and unaccommodating courts.

Participants bind themselves to the rules of their respective games by developing widely accepted customs through consent. To preserve the interactivity that defines them, video games need the freedom to traverse the negative space between the public and private spheres. Formal legal systems can provide this mobility by showing deference to their existing self-regulating systems. This is not a radical proposition. The subcultures discussed here, and the unusual canvasses they produce already occupy the legislative negative space. In Canada, they exist on the Copyright Act's invisible, non-exhaustive list that follows the definition of 'artistic work'. A cooperative approach that recognizes subcultural customs would uphold the inclusive benchmark that has already been established. Evidential burdens could be satisfied by simple formalities. For example, agreements evidenced by writing are ideal, but customs backed by evidence of widespread community usage can define the scope of implied license or inform a fair dealing analysis when disputes arise. To take the unprincipled approach; that is, to covet certain forms of artistic expression to the exclusion of others, is to view the latter through an unfamiliar eye, obscured further by an unfocused lens.

When unusual canvasses abound, they enhance our interactions with an increasingly virtual world. The ambiguous legal issues created by their subcultures should be interpreted contextually, framed by the keen, competent, and familiar lens of their communities. This framework would unburden the legal profession by minimizing its need to develop new expertise. Steadfastly regulating every facet of the 'real world' has already proven difficult enough. Subcultural experts can inform judicial decision-making by filling legal voids with their own established customs. Some negative space must be yielded to these subcultures in order to keep pace with the rapid development of creative technologies, and to ensure that they benefit from the law's full remedial capacity. Although widespread recognition by formal systems of law will inevitably transform the unusual into the usual, our system of law would be remiss to leave these canvasses buried underground, lost in a legal lacuna. Embracing the unique character and disruptive nature of online gaming environments will allow intellectual property law to uphold its inclusiveness, and become more robust by fostering diverse forms of interactive expression. 